\title{
PROTEIN FIMBRIA 16 kDa BAKTERI ACINETOBACTER BAUMANNII DARI URIN PENDERITA INFEKSI SALURAN KEMIH BERPERAN SEBAGAI PROTEIN HEMAGLUTININ DAN ADHESIN
}

\section{(THE 16 KDA FIMBRIAE PROTEIN OF ACINETOBACTER BAUMANNII FROM URINE OF URINARY TRACT INFECTION PATIENT IS HEMAGLUTININ AND ADHESION PROTEIN)}

\author{
Noorhamdani \\ Laboratorium Mikrobiologi Fakultas Kedokteran Unibraw / RSU dr Saiful Anwar Malang
}

\begin{abstract}
Acinetobacter baumannii (Acb) is an opportunistic and nosocomial pathogen that ussualy found in clinical specimen from patients with intensive care. The pathogenic mechanism of this bacteria are not fully elucidated especially potential activity of its protein as hemaglutinin and adhesion molecul. The aim of this study is to evaluate the role of $16 \mathrm{kDa}$ fimbriae protein from urnary tract infection (UTI) patient as hemaglutinin and adhesion molecule. Using explorative design this study was started by isolation Acb bacteria from urine of patient that had been determine as UTI clinically and laboratory. After identification this bacteria by microbact system hemaglutination test and isolation of its fimbriae fraction, $12.5 \%$ SDS-PAGE had been used to isolated fimbriae protein, following assay in vitro to adhesion test.. The study showed that the $16 \mathrm{kDa}$ fimbriae protein of Acb bacteria was a hemaglutinin protein that could agglutinate $0.5 \%$ mice erythrocytes (1/32), and human blood group $O$ erythrocytes (1/8). Hemaglutination test were negative on erythrocytes from rat, guinea pig, sheep, and human blood group $A, B$. The $16 \mathrm{kDa}$ fimbriae protein (AF16) was also adhesion protein that had been revealed by its activity to adherence to receptor of mice enterocytes. The increasing dose of AF16 molecules will decrease the amount of Acb bacteria to adherence to enterocytes $(p<0.05)$. The fimbriae of Acb is maybe classified P type.

Key words: Acinetobacter baumannii, fimbriae, hemaglutinin protein, adhesion protein
\end{abstract}

\section{PENDAHULUAN}

Bakteri Acinetobacter baumannii (Acb) termasuk golongan bakteri 'nonfermenter' berbentuk batang atau kokobasil Gram negatif, secara alamiah dapat dijumpai di lingkungan, tanah, air dan kotoran (1), bahkan terdapat di mukosa farings dan kulit yang sehat (2). Bakteri Acb merupakan patogen opportunistik atau patogen nosokomial, infeksi pada manusia umumnya terjadi pada penderita dengan keadaan umum yang jelek(3). Sebagai patogen nosokomial, dapat terjadi kolonisasi dan infeksi pada penderita yang di rawat di rumah sakit $(4,5,6)$. Infeksi berupa pneumonia $(3,7)$, infeksi mata $(8,9)$, infeksi luka bakar atau luka bedah, infeksi kulit, infeksi saluran kemih, bakteremia dan septikemia (3).

Bakteri tersebut dapat diisolasi dari berbagai spesimen klinik, terutama dari penderita yang memperoleh perawatan intensif $(4,5)$. Infeksi oleh Acb dapat menimbulkan masalah dalam pengobatan karena sering terjadi multiresisten terhadap berbagai macam antibiotika $(10,11,12,13,14)$. Mekanisme terjadi infeksi dari Acb belum pernah diungkapkan khususnya kemampuannya melakukan

Jurnal Kedokteran Brawijaya, Vol. XXI, No.2, Agustus 2005 Korespondensi: Noorhamdani; Lab. Mikrobiologi FK Unibraw / RSU Dr. Saiful Anwar Malang; telp.(0341)580990 adhesi pada sel hospes yang diperankan oleh protein hemaglutinin. Bakteri Acb penyebab infeksi saluran kemih mampu mengaglutnasi eritrosit mencit (15). Pada beberapa bakteri protein hemaglutinin berfungsi pula sebagai protein adhesin $(16,17,18)$. Molekul adhesin merupakan salah satu faktor virulensi dari bakteri Acb $(16,19,20)$. Tujuan penelitian ini adalah untuk membuktikan adanya protein hemaglutinin yang berfungsi sebagai adhesin, khususnya protein fimbria $16 \mathrm{kDa}$ dari bakteri Acb yang diisolasi dari urin penderita infeksi saluran kemih (ISK).

\section{METODE}

Spesimen Urin Penderita ISK

Bakteri diperoleh dari urin penderita ISK. Pengambilan spesimen urin secara aseptik dengan cara menampung urin aliran porsi tengah. Kriteria penderita ISK adalah jika urin penderita didapatkan bakteriuri bermakna $\geq 10^{5} \mathrm{CFU}$ (colony forming unit)/ml (21) dan hasil kultur urin hanya didapatkan satu jenis bakteri Acinetobacter baumannii, disertai dengan minimal dua dari tiga kriteria berikut terpenuhi yaitu suhu rektal $>38^{\circ} \mathrm{C}$ atau suhu aksiler, oral $>37^{\circ} \mathrm{C}$, laju endapan eritrosit $>25 \mathrm{~mm} / \mathrm{jam}$, serum $\mathrm{C}$ reactive protein diatas $1 \mu \mathrm{g} / \mathrm{ml}(22)$. 


\section{Bakteri Acinetobacter baumannii}

Isolasi dan identifikasi bakteri Acb menggunakan cara microbact system (23). Spesimen secara aseptik ditanam pada medium agar MacConkey dan diinkubasi pada suhu $37^{\circ} \mathrm{C}$, 18-24 jam. Koloni yang tumbuh dibuat pewarnaan Gram dan dilihat dibawah mikroskop. Identifikasi bakteri Acb dilakukan dengan pemeriksaan mikroskopis yaitu bakteri bentuk batang atau kokobasil Gram negatif. Jika di kultur pada medium agar MacConkey dan inkubasi $37^{\circ} \mathrm{C}$, tampak tumbuh baik, koloni bulat, permukaan meninggi, licin dan putih buram. Uji oksidase negatif, katalase positif, motilitas negatif dan nitrat negatif. Dengan microbact system (identifikasi final 99,99\%) diinkubasi pada suhu $37^{\circ} \mathrm{C}$, 18-24 jam : lysine (+), Ornithin (-), $\mathrm{H}_{2} \mathrm{~S}(-)$, Glukose $(+)$, Mannitol (-), Xylose (+), ONPG (-), Indole (-), Urease (), VP (-), Citrat (+) dan TDA (-). Isolat sel bakteri utuh Acb dilakukan uji hemaglutinasi (lihat prosedur), dipilih isolat dengan hasil uji hemaglutinasi positif dan dibuat kultur stok dengan cara disimpan pada suhu $-70^{\circ} \mathrm{C}$ atau $-20^{\circ} \mathrm{C}$ dalam medium cair Brain Heart Infusion (BHI) yang mengandung gliserin $22 \%$. Sebelum dilakukan manipulasi stok bakteri digandakan lebih dulu.

\section{Penggandaan (Subkultur) Isolat Acinetobacter baumannii}

Bakteri Acb dalam kultur stok dikeluarkan dari almari pendingin dan diadaptasikan dulu pada suhu ruang sampai perbenihan mencair. Kemudian ditanam pada medium agar MacConkey dan di inkubasi pada almari inkubator suhu $37^{\circ} \mathrm{C}$ selama 24 jam. Koloni yang tumbuh cek kembali dengan pewarnaan Gram, uji katalase, oksidase. Kemudian dilakukan perbanyakan dan dibiakkan pada medium yang dapat memperkaya pertumbuhan fimbria yaitu medium agar bifasik TCG yang terdiri dari medium padat agar miring TCG (thioproline carbonate glutamate) dan medium cair $\mathrm{BH}$ kemudian diinkubasi pada suhu $37^{\circ} \mathrm{C}$ selama $2 \times 24$ jam, koloni yang tumbuh dipanen dan disiapkan untuk uji. Jika akan dilakukan pemotongan fimbria, diperlukan kurang lebih 50 botol medium bifasik TCG @ 50 ml agar mendapatkan sejumlah suspensi bakteri yang cukup untuk dilakukan pemotongan dengan alat omnimixer pada suhu $4^{\circ} \mathrm{C}(16,17)$.

\section{Uji Hemaglutinasi (Uji HA)}

Uji HA dilakukan menurut McGarey dan Allred dengan sedikit modifikasi (24).

\section{Uji HA Sel Bakteri Utuh Acinetobacter baumannii}

Sampel berupa sel bakteri utuh Acinetobacter baumannii. Masing-masing sampel direaksikan dengan eritrosit mencit $0,5 \%$, dilihat titer hemaglutinasinya. Mulamula eritrosit dicuci $3 x$ dengan PBS pH 7,4, kemudian dibuat suspensi $0,5 \%$ dalam PBS. Kedalam setiap sumur dari lempeng mikrotiter dimasukkan $50 \mu \mathrm{l}$ PBS. Kedalam sumur-1 ditambahkan $50 \mu \mathrm{l}$ sampel, selanjutnya dibuat pengenceran serial kedalam sumur berikutnya, kecuali sumur-12 digunakan sebagai kontrol negatif (tanpa diberi sampel). Kemudian kedalam masing-masing sumur ditambahkan $50 \mu \mathrm{l}$ suspensi eritrosit, digoyang selama 5 menit kemudian didiamkan suhu kamar $\left(27^{\circ} \mathrm{C}\right)$ sampai terlihat hasilnya. Hasil uji hemaglutinasi untuk sampel dibaca apabila pada sumur kontrol negatif sudah terlihat hasilnya yaitu gambaran bentuk noda merah seperti kancing baju pada dasar sumur (24).

\section{Uji HA Protein Fimbria 16 kDa (F16)}

Dikerjakan sama seperti pada uji HA sel bakteri utuh Acinetobacter baumannii tersebut diatas, hanya sebagai sampelnya adalah protein fimbria F16. Bahan protein fimbria F16 diperoleh seperti prosedur tersebut dibawah ini. Uji hemaglutinasi protein fimbria selain dilakukan terhadap eritrosit mencit, juga dilakukan terhadap eritrosit manusia golongan darah $\mathrm{A}, \mathrm{B}$ dan $\mathrm{O}$, serta eritrosit marmot dan domba, prosedurnya sama dengan uji HA tersebut diatas hanya yang berbeda jenis eritrosit yang digunakan (24).

Isolasi dan Purifikasi Fraksi Fimbria dari Bakteri Acinetobacter baumannii

\section{Pemisahan Fimbria dari Bagian Sel}

Biakan cair dari medium bifasik dipindahkan ke dalam tabung sentrifus $100 \mathrm{ml}$, ditambahkan TCA (Trichloroacetic acid) sehingga konsentrasinya $3 \%$, kemudian diputar pada sentrifus dingin $4^{\circ} \mathrm{C} 6000 \mathrm{rpm}$ selama 15 menit. Endapan disuspensi dengan PBS pH 7,4 sebanyak 3-5 kali volume, kemudian dilakukan pemotongan fimbria menggunakan alat omnimixer pada suhu $4^{\circ} \mathrm{C}$ $(16,17)$. Sampel kemudian diputar dalam sentrifus dingin $4^{\circ} \mathrm{C} 12.000 \mathrm{rpm}$ selama 15 menit. Supernatan dipisahkan (mengandung fraksi frimbia) dan endapan disuspensi dengan PBS pH 7,4 seperti pada pemotongan pertama, kemudian dilakukan pemotongan fimbria lagi. Proses ini diulang sampai 5 kali. Dari prosedur ini, diperoleh supernatan yang mengandung fraksi fimbria dan endapan yang merupakan bagian sel bakteri (25). Bahan sediaan tersebut kemudian disimpan pada suhu $-20^{\circ} \mathrm{C}$ sampai digunakan untuk pemeriksaan berikutnya.

\section{Fraksinasi Fimbria}

Fraksi fimbria dikumpulkan, dilakukan proses dialisis menggunakan larutan $\mathrm{PBS} \mathrm{pH} 7,4$ pada suhu $4^{\circ} \mathrm{C}$ selama 2 $X 24$ jam untuk menghilangkan sisa TCA. Selanjutnya dialisat diendapkan dengan ammonium sulfat $35 \%$, diputar 6000 rpm dan suhu $4^{\circ} \mathrm{C}$, kemudian supernatan dibuang, endapan disuspensi dengan PBS secukupnya dan dilakukan dialisis kembali. Hasil dialisis merupakan protein fraksi fimbria dan disimpan pada suhu $-20^{\circ} \mathrm{C}$ sampai digunakan untuk pemeriksaan selanjutnya (25).

\section{Isolasi Protein Fimbria 16 kDa}

\section{Perkiraan Berat Molekul Protein Fimbria Acb}

Dibuat preparasi fraksi fimbria pada tabung ependorf masing-masing sebanyak $500 \mu \mathrm{l}$ dalam PBS dan ditambah 
volume sama suspensi eritrosit $0,5 \%$. Sesudah terjadi hemaglutinasi, kemudian disentrifus $3000 \mathrm{rpm}$ selama 15 menit, selanjutnya supernatan dipisahkan dari endapan. Dilakukan SDS-PAGE 12,5\% menurut metode Laemli (26) terhadap fraksi fimbria, supernatan dan endapan hasil hemaglutinasi (aglutinat) dari fimbria serta eritrosit mencit (kontrol). Protein hemaglutinin adalah protein yang terdapat pada hasil elektroforesis aglutinat, tetapi tidak terdapat pada hasil elektroforesis eritrosit mencit. Kemudian ditentukan berat molekul dari protein hemaglutinin tersebut berdasarkan protein perunut (protein marker).

\section{Elektroelusi Protein Fimbria F16 Untuk Uji}

Gel hasil SDS-PAGE 12,5\% sebanyak 6-8 lembar yang terdapat pita protein subfraksi fimbria pada posisi berat molekul yang diinginkan (sesuai perkiraan berat molekul protein fimbria Acb), dipotong secara mendatar pada sisi atas dan bawah pita. Kemudian potonganpotongan pita dikumpulkan sesuai berat molekul dan jenis proteinnya dimasukkan membran dialisis untuk dilakukan elektroelusi menggunakan alat electroforesis horizontal apparatus, dengan larutan penyangga electroforesis running buffer, aliran listrik 125 volt selama 2 jam. Hasil elektroelusi dilakukan dialisis dengan larutan PBS pH 7,4 selama 2 X 24 jam, larutan diganti setiap 24 jam. Eluat di endapkan dengan larutan etanol absolut dingin semalam, sehingga diperoleh endapan protein murni yang siap digunakan untuk uji berikutnya (17).

\section{Uji (Hambatan) Hemaglutinasi oleh Gula D-mannose}

Uji hambat hemaglutinasi terhadap D-mannose, bertujuan untuk mengetahui sensitivitas protein fraksi fimbria terhadap D-mannose.

Menggunakan lempeng mikrotiter, kedalam masingmasing sumur dimasukkan larutan PBS pH 7.4 sebanyak $50 \mu \mathrm{l}$. Selanjutnya pada sumur ke-1 ditambahkan Dmannose $1 \mathrm{M}$ sebanyak $50 \mu \mathrm{l}$ dan dilakukan pengenceran serial sampai sumur ke-10. Sesudah itu ke dalam masingmasing sumur dimasukkan protein fimbria (kadar sesuai dengan titer HA tertinggi) dalam PBS pH 7.4 sebanyak $50 \mu \mathrm{l}$ sampai sumur ke-10. Kemudian ke dalam masing-masing sumur pada lempeng mikrotiter tersebut selanjutnya ditambahkan suspensi eritrosit mencit $0,5 \%$ sebanyak 50 $\mu$, digoyang selama 5 menit. Lempeng mikrotiter didiamkan suhu kamar $\left(27^{\circ} \mathrm{C}\right)$ sampai hasilnya terlihat. Sumur ke -11 digunakan sebagi kontrol hemaglutinasi negatif (berisi $D$ mannose dan eritrosit saja tanpa protein fimbria), sedangkan sumur ke-12 digunakan sebagai kontrol hemaglutinasi positif (berisi protein fimbria dan eritrosit saja tanpa penambahan D-mannose)(16).

\section{Uji Adhesi Protein Fimbria F16}

\section{(1) Isolasi Enterosit Mencit}

Isolasi enterosit mencit dilakukan menurut metode Weisser (27). Mencit dimatikan dengan menggunakan khloroform, perut dibuka dan usus halus dipisahkan. Usus halus dipotong kecil-kecil, kotoran dibersihkan, dicuci beberapa kali sampai bersih di dalam larutan PBS dingin $\left(4^{\circ} \mathrm{C}\right)$ yang mengandung $1 \mathrm{mM}$ dithiothretol. Kemudian jaringan usus dimasukkan ke dalam cairan yang mengandung 1,5 mM KCl, 9,6 mM NaCl, 27mM Na-citrat, 8

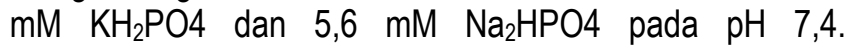
Campuran diinkubasi pada shaking incubator $37^{\circ} \mathrm{C}$. Supernatan dibuang dan jaringan dicuci $3 x$ dengan PBS, kemudian disentrifugasi $1500 \mathrm{rpm}$, pada suhu $4^{\circ} \mathrm{C}$ selama 5 menit. Enterosit diperoleh pada bagian cairan setelah melakukan resuspensi pada jaringan menggunakan larutan PBS yang mengandung bovine serum albumin (BSA) $1 \%$. Selanjutnya jumlah sel dihitung menggunakan hemositometer, dan jumlah enterosit yang digunakan untuk uji adhesi adalah $10^{6} / \mathrm{ml}(27)$.

\section{(2) Prosedur Uji Adhesi}

Bakteri Acb dibiakkan pada medium cair BHI pada suhu $37^{\circ} \mathrm{C}$ selama 24 jam. Biakan cair disentrifugasi 6000 rpm, pada suhu $4^{\circ} \mathrm{C}$ selama 10 menit. Endapan disuspensikan didalam PBS yang mengandung BSA $1 \%$. Selanjutnya kandungan bakteri dibuat $108 / \mathrm{ml}$ (konsentrasi sel pada $O D=1,0 \lambda=600 \mathrm{~nm}$ adalah $8 \times 10^{8} / \mathrm{ml}$ ) (28).

Dibuat preparasi dosis protein fimbria masing-masing sebanyak $0 \mu \mathrm{g}$ (kontrol), $25 \mu \mathrm{g}, 50 \mu \mathrm{g}, 100 \mu \mathrm{g}, 200 \mu \mathrm{g}$, $400 \mu \mathrm{g}$ dan $800 \mu \mathrm{g}$ dalam $300 \mu \mathrm{l}$ PBS dalam ependorf. Selanjutnya terhadap masing-masing ependorf dtambahkan suspensi enterosit sebanyak $300 \mu \mathrm{l}$ dan digoyang perlahan pada shaking waterbath pada suhu $37^{\circ} \mathrm{C}$ selama 30 menit. Kemudian ke dalam setiap campuran tersebut ditambah suspensi bakteri $\left(10^{8} / \mathrm{ml}\right)$ sebanyak $300 \mu$ l. Campuran diinkubasi pada shaking incubator selama 30 menit pada suhu $37^{\circ} \mathrm{C}$. Selanjutnya disentrifugasi $1500 \mathrm{rpm}$, pada suhu $4^{\circ} \mathrm{C}$ selama 3 menit, kemudian endapan dicuci 2 kali dengan PBS. Endapan diambil, dibuat hapusan pada gelas objek dan dicat dengan pewarnaan Gram. Preparat diamati dibawah mikroskop pembesaran 1000 kali, dan dihitung jumlah rerata bakteri yang menempel pada enterosit. Indeks adhesi adalah jumlah rerata bakteri yang menempel pada enterosit, dihitung untuk setiap pengamatan terhadap 100 enterosit $(16,29,30)$.

\section{3) Analisis Statistik (31)}

Menggunakan ANOVA dan uji Tukey, dengan batas signifikan 0,05. 
HASIL PENELITIAN

Hasil Uji HA Sel Bakteri Utuh Acinetobacter baumannii

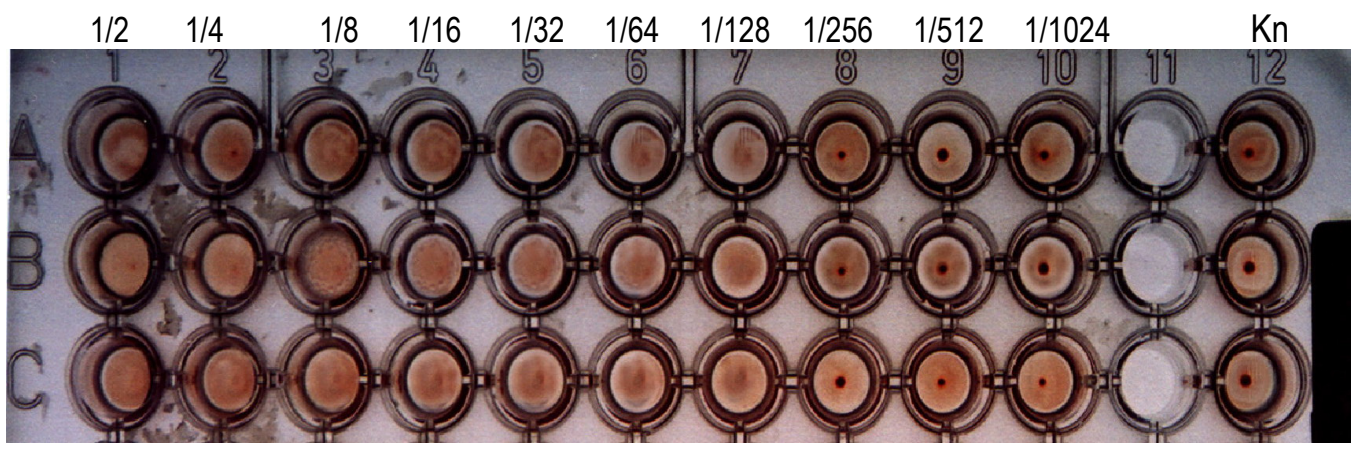

Gambar 1. Hasil Uji Hemaglutinasi Menggunakan Eritrosit Mencit 0,5\% Terhadap Bakteri Acinetobacter baumannii Keterangan: (Acb)

Angka 1/2 - 1/1024: menunjukkan besar titer (pengenceran) sampel (berisi sampel, PBS dan eritrosit). Kn: kontrol reaksi negatif, berisi eritrosit dan PBS, tanpa sampel, tidak terjadi penggumpalan eritrosit (tampak gambar bentukan noda merah seperti kancing baju pada dasar sumur). Pada baris A, sampel isolat klinik Acb193 (urin, HA positif titer 1/128, yang akan diisolasi protein fimbria); B, isolat klinik Acb1508 (sputum, HA positif titer 1/128);C, isolat klinik Acb2797(pus, HA positif titer 1/128).

\section{Hasil Elektroforesis}

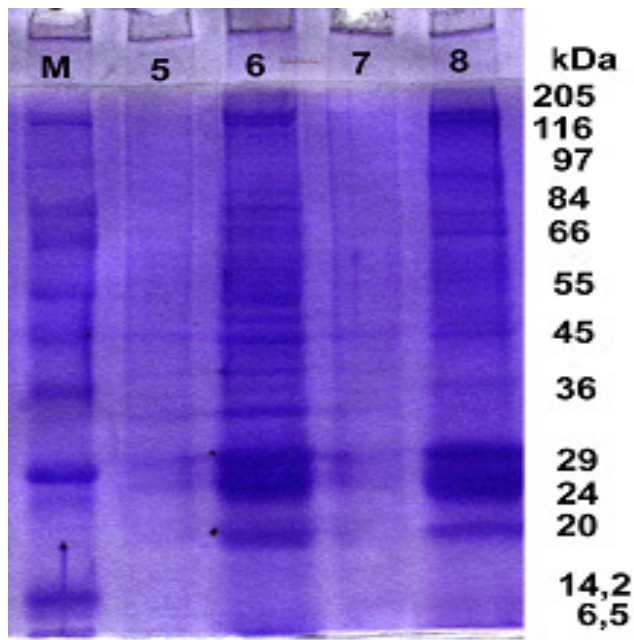

Keterangan :

\section{Gambar 2.Hasil Elektroforesis SDS-PAGE 12,5\% dari Protein Fimbria Bakteri Acb.}

Lajur- $M$ : protein perunut (Sigma); lajur-5: fraksi fimbria; lajur-6: endapan aglutinat fimbria; lajur-7: supernatan aglutinat fimbria;lajur 8-: eritrosit mencit. Supernatan dan endapan aglutinat didapat dari pemisahan dengan sentrifugasi $3000 \mathrm{rpm}$ kompleks sampel-eritrosit hemaglutinasi positif.

Gambar 2 pada lajur-5 (fraksi fimbria) dan lajur-6 (endapan aglutinat fimbria) didapat 2 pita pada posisi 38,5 $\mathrm{kDa}$ dan $30,5 \mathrm{kDa}$, tetapi tidak didapatkan pada lajur-8 (eritrosit), dan satu pita pada posisi $16 \mathrm{kDa}$ pada lajur-6 tampak lebih tebal dan lebar dibandingkan dengan lajur-8 (eritrosit). Hal ini menunjukkan bahwa ada protein subfraksi fimbria yang melekat pada eritrosit dan protein tersebut memperantarai terjadinya hemaglutinasi, diyakini bahwa diantara ketiga pita protein tersebut adalah protein hemaglutinin dari fimbria.

$\mathrm{kDa}$

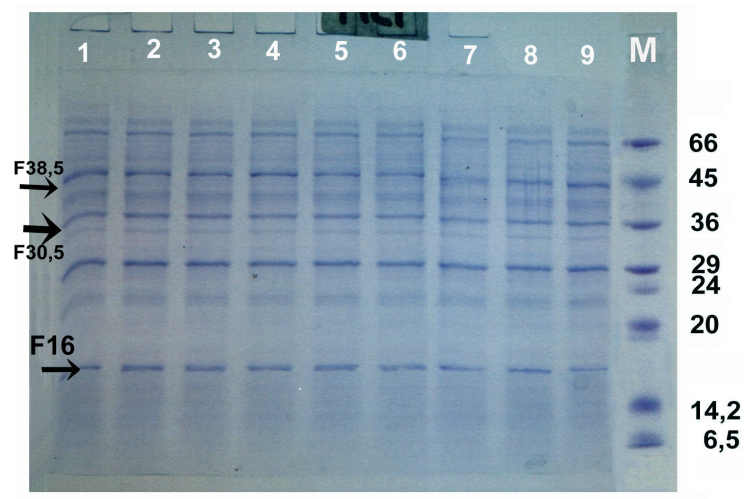

Gambar 3. Hasil Elektroforesis SDS-PAGE 12,5\% dari Protein Fraksi Fimbria

Keterangan :

Lajur 1- 9 : protein fraksi fimbria; lajur $M$ : protein perunut(Sigma). Tampak pita protein dengan BM 38,5 kDa, 30,5 kDa dan $16 \mathrm{kDa}$ yang dapat diamati pada lajur-1 s/d 9. Pita-pita protein tersebut akan dipotong dan dimurnikan dengan cara elektroelusi sebagai bahan dasar dan disiapkan untuk uji berikutnya.

\section{Hasil Uji HA Protein Fimbria F16 Terhadap Berbagai Jenis Eritrosit}

Tabel 1, menunjukkan protein fimbria F16 dapat mengaglutinasi eritrosit mencit dengan titer $1 / 32$, dan eritrosit manusia golongan darah 0 dengan titer $1 / 8$. Protein fimbria F16 terhadap eritrosit tikus, marmot, domba, manusia golongan darah $\mathrm{A}$ dan $\mathrm{B}$ memberikan reaksi 
negatif. Dengan perkataan lain bahwa reseptor terhadap protein fimbria F16 pada permukaan eritrosit mencit mungkin memiliki kemiripan atau sama dengan reseptor yang ada dipermukaan eritrosit manusia golongan darah $\mathrm{O}$. Berdasar homologi reseptor pada eritrosit dengan reseptor sel epitel hospes lainnya, maka diduga manusia golongan darah $O$ lebih peka terhadap infeksi Acinetobacter baumannii.

Tabel 1. Hasil Uji Hemaglutinasi Protein Fimbria F16 Terhadap Berbagai Jenis Eritrosit Hewan dan Manusia.

\begin{tabular}{lc}
\hline $\begin{array}{l}\text { Sampel } \\
\text { Eritrosit }\end{array}$ & F16 \\
\hline Mencit & $1 / 32$ \\
\hline Tikus & - \\
\hline Marmot & - \\
\hline Domba & - \\
\hline Man A & - \\
\hline Man B & - \\
\hline Man O & $1 / 8$ \\
\hline Keterangan: &
\end{tabular}

Uji HA menggunakan kadar eritrosit 0.5\% dalam PBS; F16: Protein fimbria BM 16 kDa dari bakteri Acb; Man A, Man B, Man $O$ : eritrosit manusia golongan darah $A, B$ dan 0 .

Hasil Uji (Hambat) Hemaglutinasi oleh Gula D-mannose.

Percobaan ini bertujuan untuk mengetahui kepekaan protein fimbria F16 terhadap D-mannose. Prosedur hampir sama dengan uji hemaglutinasi yaitu menggunakan eritrosit $0,5 \%$, tetapi sampel protein fimbria F16 disalut terlebih dahulu dengan D-mannose kemudian baru direaksikan dengan eritrosit. Hasil disebut sensitif terhadap D-mannose (mannose sensitif) jika terjadi hambatan hemaglutinasi dan disebut resisten terhadap D-mannose (mannose resistant) jika tidak terjadi hambatan hemaglutinasi.

Percobaan ini menggunakan eritrosit manusia golongan $\mathrm{O}$ dan hasilnya menunjukkan bahwa protein fimbria F16 adalah resisten terhadap D-mannose (gambar tidak direkam), berarti bahwa dengan pemberian gula Dmannose tidak mampu menghambat reaksi hemaglutinasi atau reaksi hemaglutinasi terhadap eritrosit masih tetap berlangsung karena tidak terbentuk ikatan komplek protein (sebagai ligand)-D-mannose (sebagai reseptor). Dengan demikian diyakini pula bahwa reseptor terhadap molekul protein fimbria F16 adalah bukan D-mannose.

\section{Hasil Uji Adhesi Terhadap Protein Fimbria F16}

Hasil foto gambaran adhesi Acinetobacter baumannii yang ditampilkan disini adalah untuk protein fimbria dosis 0 $\mu \mathrm{g}$ (kontrol), $100 \mu \mathrm{g}$ dan $800 \mu \mathrm{g}$, karena alasan keterbatasan, gambaran adhesi terhadap dosis yang lain tidak ditampilkan.

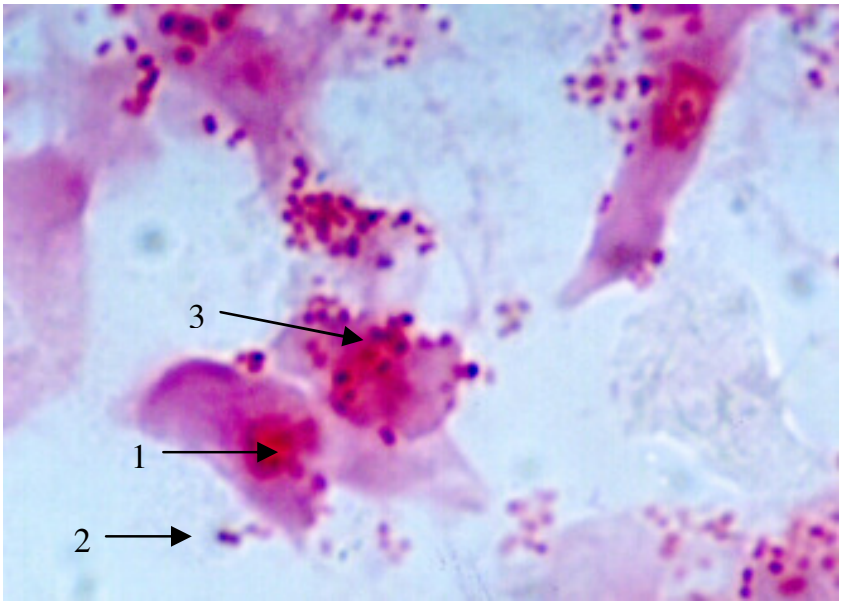

Gambar 4 (a). Adhesi Acb pada Enterosit Mencit Tanpa Disalut dengan Protein Fimbria F16 dari Acb (dosis $0 \mu \mathrm{g}$, kontrol).

Keterangan : 1. Enterosit, 2. Sel bakteri Acb, 3. Adhesi tipe difus.Pewarnaan Gram, pembesaran $1000 \mathrm{X}$ dan direkam dengan kamera Nikon.

Gambar $4(\mathrm{a})$, hasil perlakuan dosis $0 \mu \mathrm{g}$ protein fimbria F16 sebagai kontrol, enterosit langsung direaksikan dengan bakteri Acinetobacter baumannii. Sel-sel bakteri Acinetobacter baumannii tampak berbentuk kokobasil Gram negatif, berpasangan dua-dua, banyak melekat dan mengelilingi permukaan enterosit mencit. Dapat diamati pula kumpulan sel-sel bakteri melekat menyelimuti secara merata pada permukaan enterosit, gambaran ini dikenal sebagai adhesi tipe difus. Gambaran adhesi tipe difus tampak pada beberapa pengamatan khususnya pada perlakuan dosis $0 \mu \mathrm{g}$.

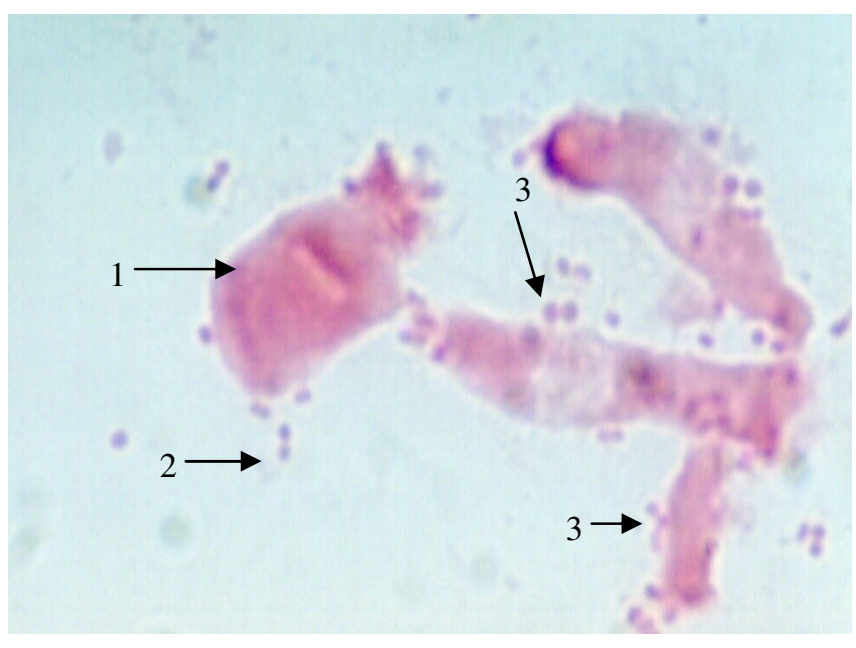

Gambar 4(b). Adhesi Acb pada Enterosit Mencit yang Sebelumnya Sudah Disalut dengan Protein Fimbria F16 dari Acb (dosis 100 $\mu \mathrm{g})$

Keterangan :1. Enterosit, 2. Sel bakteri Acb, 3. Adhesi tipe lokal.Pewarnaan Gram, pembesaran 1000 X dan direkam dengan kamera Nikon. 
Gambar 4 (b), hasil perlakuan dosis $100 \mu \mathrm{g}$ protein fimbria F16, tampak sel-sel bakteri yang melekat pada sel epitel enterosit semakin berkurang jika dibandingkan dengan pemberian dosis $0 \mu \mathrm{g}$ dan $25 \mu \mathrm{g}$ dan analisis statistik menunjukkan beda bermakna $(p<0,05)$. Hasil beberapa pengamatan tampak sel bakteri melekat pada sel epitel enterosit sebagai adhesi tipe lokal.

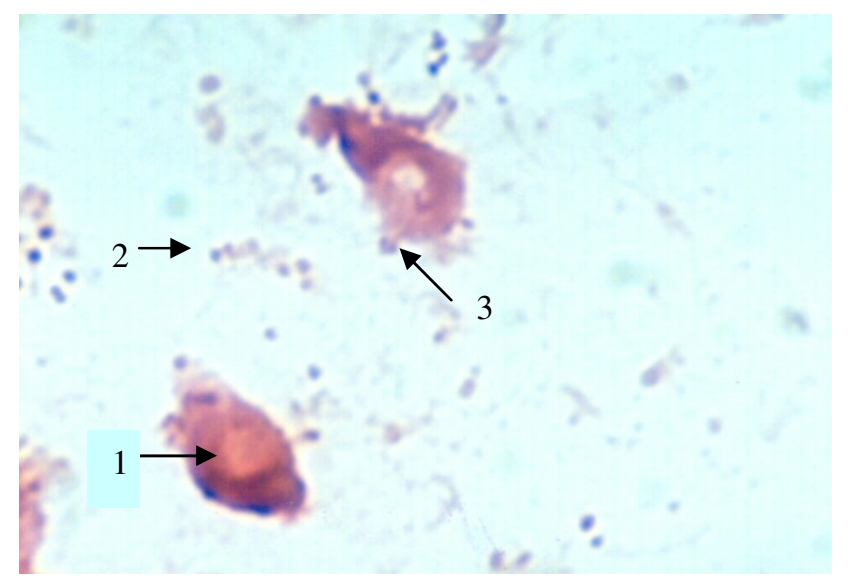

Gambar 4 (c). Adhesi Acb pada Enterosit Mencit yang Sebelumnya Sudah Disalut dengan Protein Fimbria F16 dari Acb (dosis 800

Keterangan : $\mu g)$

1. Enterosit, 2. Sel bakteri Acb, 3. Adhesi tipe lokal.Pewarnaan Gram, pembesaran $1000 X$ dan direkam dengan kamera Nikon.

Gambar 4 (c), pemberian dosis $800 \mu \mathrm{g}$ protein fimbria F16 tampak sel-sel bakteri sekitar 1-3 sel yang melekat pada sel epitel enterosit. Merujuk Tabel 2, jika dibandingkan dengan pemberian dosis yang lain, dosis 800 $\mu \mathrm{g}$ menghasilkan indeks adhesi terkecil dan berbeda bermakna dengan dosis yang lain $(p<0,5)$.

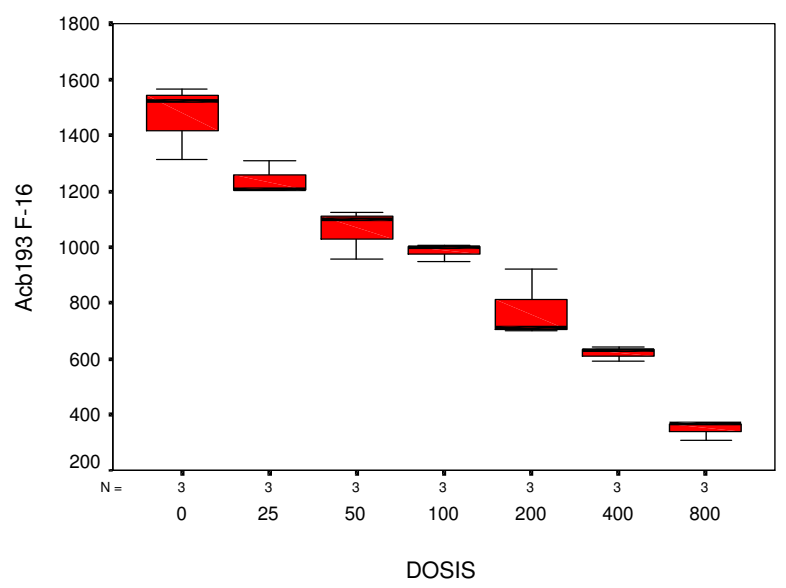

Gambar 5. Diagram Garis Kotak Indeks Adhesi Berdasarkan Dosis $(\mu \mathrm{g})$ Protein Fimbria F16 dari Bakteri Acb
Hasil penelitian seperti ditampilkan pada Gambar 5 dan Tabel 2, menunjukkan bahwa protein fimbria F16 dosis $25 \mu \mathrm{g}$ belum mampu menurunkan indeks adhesi secara bermakna dibandingkan dengan dosis $0 \mu \mathrm{g}$ (kontrol) dan kontrol baru berbeda bermakna dengan dosis $50 \mu \mathrm{g}$ ke atas. Dosis $25 \mu \mathrm{g}$ belum berbeda bermakna dengan dosis $50 \mu \mathrm{g}$ dan tampak berbeda bermakna dengan dosis $100 \mu \mathrm{g}$ ke atas. Selanjutnya dosis $50 \mu \mathrm{g}$ menunjukkan adanya perbedaan yang bermakna dengan dosis $200 \mu \mathrm{g}$ ke atas, kemudian dosis $100 \mu \mathrm{g}$ tampak berbeda bermakna dengan dosis $400 \mu \mathrm{g}$ ke atas. Dosis $200 \mu \mathrm{g}$ masih belum berbeda dengan dosis $400 \mu \mathrm{g}$, sedangkan dosis $800 \mu \mathrm{g}$ menghasilkan indeks adhesi terkecil dan berbeda bermakna dengan dosis lainnya.

Tabel 2. Nilai Rerata Indeks Adhesi dan Hasil Pembandingan Berganda Efek Dosis Protein Fimbria F16

\begin{tabular}{cl}
\hline DOSIS F16 & INDEKS ADHESI \\
\hline $\mathbf{0}$ & $1467.33 \mathrm{a}$ \\
\hline $\mathbf{2 5}$ & $1240.67 \mathrm{ab}$ \\
\hline $\mathbf{5 0}$ & $1061.33 \mathrm{bc}$ \\
\hline $\mathbf{1 0 0}$ & $986.00 \mathrm{~cd}$ \\
\hline $\mathbf{2 0 0}$ & $776.67 \mathrm{de}$ \\
\hline $\mathbf{4 0 0}$ & $619.67 \mathrm{e}$ \\
\hline $\mathbf{8 0 0}$ & $349.00 \mathrm{f}$ \\
\hline
\end{tabular}

Keterangan:

Angka di dalam kolom yang sama yang didampingi huruf berbeda adalah berbeda bermakna pada uji Tukey $\alpha=0.05$

Berdasarkan dari percobaan tersebut di atas, sebagaimana hasil yang ditampilkan pada Gambar 4 (a-c), Gambar 5 dan Tabel 2, dengan pemberian dosis yang semakin meningkat akan diikuti dengan menurunnya indeks adhesi, maka dapat disimpulkan bahwa protein fimbria dengan berat molekul $16 \mathrm{kDa}$ juga berfungsi sebagai protein adhesin dan selanjutnya disebut protein adhesin fimbria (AF16).

\section{DISKUSI}

Bakteri Acinetobacter sebelumnya dikenal dengan nama Mima polymorpha dan Herellea vaginicola. Sedang spesies Acb sebelumnya dikenal dengan nama Acinetobacter calcoaceticus var. anitratus, atau lebih sering disebut Acinetobacter anitratus (32). Dengan teknik hibridisasi DNA telah diketahui 21 genomospesies dari bakteri Acinetobacter spp. (33), bakteri Acb dikelompokkan dalam genomo-spesies 2. 
Gambar 1. tampak isolat Acb berasal dari urin penderita ISK menunjukkan hasil uji hemaglutinasi positif, diyakini isolat tersebut memiliki protein hemaglutinin, yang terbukti seperti hasil pada Tabel 1. Ekstraksi protein fimbria $16 \mathrm{kDa}$ memberikan uji hemaglutinasi positif baik terhadap eritrosit mencit maupun manusia golongan darah 0 , masing-masing dengan titer sebesar $1 / 32$ dan $1 / 8$. Sedang terhadap eritrosit tikus, marmot, domba, manusia golongan darah A dan B memberikan reaksi negatif (Tabel 1). Hasil ini membuktikan bahwa protein fimbria $16 \mathrm{kDa}$ adalah merupakan protein hemaglutinin. Protein hemaglutinin dianggap sebagai salah satu faktor virulensi dari bakteri patogen $(34,35)$. Bakteri yang mampu mengaglutinasi eritrosit memiliki kemampuan pula melakukan adhesi pada sel mukosa hospes $(27,36,37)$.

Hasil perkiraan berat molekul protein fimbria didapatkan 3 macam yaitu 38,5 kDa, 30,5 kDa dan $16 \mathrm{kDa}$ (Gambar 2), kemungkinan protein $38,5 \mathrm{kDa}$ dan $30,5 \mathrm{kDa}$ merupakan protein polimer dari subunit fimbria Acb, seperti yang telah ditemukan pada bakteri Vibrio cholerae 01 M094V (17).

Kemampuan melakukan adhesi diperantarai oleh molekul adhesin, baik yang berasal dari fimbria maupun OMP (outer membrane protein) $(16,17,19,20)$. Protein fimbria $16 \mathrm{kDa}$ terbukti sebagai molekul adhesin, seperti hasil yang terlihat pada Gambar 4 (a,b,c,d) dan Tabel 2. Dengan demikian, isolat bakteri Acb tersebut memiliki protein hemaglutinin yang berperan pula sebagai molekul adhesin yang diperantarai oleh molekul protein fimbria 16 $\mathrm{kDa}$ (AF16).

Pada bakteri Salmonella typhi (16), Vibrio cholerae (17), dan Bordetella pertussis (18) memiliki protein hemaglutinin yang berperan pula sebagai adhesin dan bersifat antigenik. Pada bakteri Vibrio parahaemolyticus (27), Klebsiella pneumoniae (29) dan Helicobacter pylori (38) memiliki molekul protein adhesin yang mampu melakukan hemaglutinasi eritrosit.

Molekul protein adhesin yang bersifat antigenik merupakan antigen yang baik untuk menimbulkan antibodi spesifik, sehingga diharapkan molekul adhesin bisa dikembangkan sebagai kandidat vaksin (16). Molekul AF16 diyakini pula bersifat antigenik yang hasil selengkapnya akan dilaporkan kemudian. Sifat protein hemaglutinin yang imunogenik banyak dijumpai pada bakteri lain. Protein hemaglutinin Helicobacter pylori dengan berat molekul 20 $\mathrm{kDa}$ (38) bersifat antigenik. Protein hemaglutinin pada bakteri Bordetella pertussis, disamping berfungsi sebagai adhesin juga dapat merangsang timbulnya respon imun (18). Bakteri Salmonella typhi memiliki protein hemaglutinin dari fraksi fimbria dan OMP masing-masing dengan BM $36 \mathrm{kDa}$ berfungsi pula sebagai molekul adhesin dan bersifat imunogenik yang protektif (16).
Penelitian tentang protein adhesin sebagai kandidat vaksin tampak memberikan harapan dimasa depan. Imunisasi mencit dengan FimH dapat menurunkan kolonisasi bakteri Escherichia coli pada kandung kemih lebih dari 99\% (20). Sebagian besar peneliti telah menyepakati bahwa vaksin yang mengandung peptida PapG efektif dalam mencegah ISK yang disebabkan oleh bakteri berfimbria tipe $P$. Pemberian fraksi fimbria utuh tipe $P$ secara intra kandung kemih atau intraurethra pada hewan coba mencit BALB/c dan kera, ternyata sangat imunogenik dan protektif terhadap terjadinya pyelonefritis (39). Berdasar hasil penelitian tersebut, maka perlu penelitian lanjut untuk menentukan apakah molekul adhesin AF16 memiliki potensi antigenik yang protektif untuk bisa dikembangkan sebagai vaksin.

Protein hemaglutinin bakteri dapat berasal dari fimbria dan atau OMP. Struktur bakteri yang berperan dalam perlekatan adalah pili atau fimbria yang tersusun dari protein yang disebut pilin (fimbrial-adhesin), atau afimbrialadhesin yaitu suatu protein yang terdapat pada permukaan sel bakteri $(19,20)$. Adhesin pada beberapa bakteri berupa protein yang dapat mengaglutinasi eritrosit yang dikenal sebagai protein hemaglutinin $(27,37)$.

Kemampuan protein hemaglutinin mengaglutinasi berbagai jenis eritrosit hewan tidak sama $(16,17,30)$. Pada penelitian ini didapatkan hasil yang bervariasi pula. Protein fimbria F16 dapat mengaglutinasi eritrosit mencit dan manusia golongan darah $\mathrm{O}$, tetapi tidak dapat mengaglutinasi eritrosit domba, marmot, tikus, manusia golongan darah A dan B. Data tersebut menunjukkan bahwa aktivitas hemaglutinasi bakteri Acb terhadap berbagai jenis eritrosit berbeda dengan bakteri lain. Aktivitas hemaglutinasi Campylobacter pylori terhadap eritosit mencit, kelinci, marmot, domba, kuda dan manusia menghasilkan reaksi positif (40). Vibrio cholerae 01 M094V memiliki protein fimbria dan OMP masing-masing dengan berat molekul $38 \mathrm{kDa}$ mampu mengaglutinasi eritrosit mencit, kelinci, dan darah manusia golongan darah 0 , tetapi tidak mampu mengaglutinasi eritrosit marmot, manusia golongan darah $A, B$ dan $A B$ (17). Bakteri Salmonella typhi memiliki protein hemaglutinin adhesin fimbria dan OMP masing-masing dengan berat molekul $36 \mathrm{kDa}$ mampu mengaglutinasi eritrosit mencit, marmot dan manusia golongan darah $O$, tetapi tidak mampu mengaglutinasi eritrosit domba, manusia golongan darah $A, B$, dan $A B$ (16).

Sehubungan dengan kemampuan bakteri Acb mengaglutinasi eritrosit manusia golongan darah $\mathrm{O}$, demikian pula pada bakteri lain misalnya Vibrio cholerae 01 M094V (17) dan Salmonella typhi (16), memberi petunjuk bahwa pada permukaan eritrosit golongan darah 0 terdapat reseptor yang komplementer dan mampu berikatan spesifik dengan adhesin dari berbagai jenis mikroba, khususnya 
bakteri Gram negatif. Karena reseptor pada permukaan eritrosit mirip dengan reseptor sel epitel hospes lainnya khususnya sel epitel yang menjadi tempat kolonisasi (36), maka diduga manusia golongan darah 0 pada permukaan eritrosit dan sel epitelnya memiliki reseptor yang cocok dan komplementer dengan adhesin dari mikroba patogen dibandingkan dengan manusia golongan darah $A, B$ dan $A B$, sehingga manusia golongan darah $O$ lebih peka terhadap infeksi mikroba termasuk bakteri Acb. Bukti tersebut didukung fakta empirik lain bahwa kejadian penyakit tukak lambung (Peptic ulcer disease) yang disebabkan oleh Helicobacter pylori meningkat pada manusia golongan darah $\mathrm{O}(41)$, penderita golongan darah O lebih peka terhadap infeksi jamur Pityrosporum ovale (42). Infeksi virus Norwalk sering menyerang penderita golongan darah $\mathrm{O}$ dan menunjukkan terdapat suatu hubungan antara faktor genetik dan resiko terkena infeksi virus Norwalk (43). Namun, masih diperlukan penelitian lebih lanjut untuk mengetahui faktor yang mempengaruhi kerentanan manusia golongan darah 0 terhadap infeksi oleh mikroba, khususnya Acb.

Fakta emperik penelitian ini menunjukkan bahwa protein fimbria F16 merupakan subfraksi fimbria yang tidak mampu mengaglutinasi eritrosit marmot, tetapi terhadap eritrosit manusia golongan darah 0 memberikan reaksi positif dan dengan penambahan D-mannose tidak mampu menghambat reaksi hemaglutinasinya (resisten terhadap Dmannose), sehingga lebih cenderung dikategorikan memiliki karakteristik seperti fimbria tipe $P$. Fimbria tipe $P$ adalah fimbria yang mampu mengaglutinasi eritrosit manusia dan reaksi hemaglutinasinya tidak dapat dihambat oleh mannose (mannose resistant) (22).

Adhesin fimbria tipe $P$ adalah suatu ligand yang dapat melekat pada reseptor sel hospes yang komplementer berupa globobiose (19) atau globoseries (44) yaitu suatu disakharida $\alpha$-D-galactopyranosyl-(1-4)- $\beta$-D-galactopyranoside (ikatan adhesi GAL-GAL) (32). Fimbria tipe $P$ adalah yang sering berperan pada adhesi bakteri Escherichia coli uropatogen pada sel epitel mukosa saluran kemih (45), yang dikaitkan dengan infeksi pyelonefritis akut (44).

\section{KESIMPULAN DAN SARAN}

Telah dibuktikan bakteri Acinetobacter baumannii isolat dari urin penderita infeksi saluran kemih, memilki protein fimbria dengan berat molekul $16 \mathrm{kDa}$ (AF16) yang merupakan protein hemaglutinin dan berperanan pula sebagai molekul adhesin dan diyakini sebagai salah satu faktor virulensi. Diduga bakteri Acinetobacter baumannii memiliki fimbria tipe $P$ yang berperan pada proses adhesi dalam menyebabkan infeksi. Walaupun masih diperlukan penelitian lebih lanjut, molekul protein hemaglutinin adhesin AF16 dapat dikembangkan sebagai kandidat vaksin dalam upaya pencegahan infeksi.

\section{DAFTAR KEPUSTAKAAN}

1. Holt JG, Krieg NR, Sneath PHA, Staley JT, Williams ST. Bergey's Manual of Determinative of Bacteriology, $9^{\text {th }}$. Baltimor: William \& Wilkins; 1994.

2. Seifert H, Dijkshoorn L, Gerner-Smidt P, Pelzer N, Tjernberg I and Vaneechoutte. Distribution of Acinetobacter species on Human skin: Comparison of Phenotypic and Genotypic Identification Methods. J Clin Microbiol 1997; 35: 2819-2825.

3. Holmes B and Howard BJ. Nonfermentative Gram-Negative Bacteria. In: Clinical and Pathogenic Microbiology, $2^{\text {nd }}$ ed. Howard BJ et al (ed.), St Louis, Washington DC, Toronto: CV Mosby Co; 1994; 337-364.

4. Gould IM, MacKenzie F, Thomson C. Acinetobacter Infections, Intensive Care Units, and Handwashing (letter; comment). Lancet 1995; 345: 122.

5. Humpreys H, Towner KJ, Crowe M, Webster C, Winter R. Acinetobacter Infections, Intensive Care Units, Handwashing (letter). Lancet 1995; 345:121.

6. Scerpella EG, Wanger AR, Armitige L, Anderlini P, Ericsson CD. Nosocomial Outbreak Caused by a Multiresistent Clone of: Results of Case Control and Molecular Epidemiologic Investigations. Infect Control Hosp Epidemiol 1995; 16: 92-97.

7. Bilgic H, Akin ES, Tasan Y, Ekiz K, Seber O. A case of Acinetobacter calcoaceticus Pneumonia. Thorax 1995; 50: 315316.

8. Khater TT, Jones DB, Wilhelmus KR. Infectious Crystalline Keratopathy Caused by Gram-Negative Bacteria. American J Ophthalmology 1997; 124: 19-23.

9. Kirwan JF, Potamitis T, el-Kasaby H, Hope-Ross Mw, Sutton GA. Microbial Keratitis in Intensive Care. B Med J 1997; 314: 433-534.

10. Josodiwondo S. Perbandingan Pola Kepekaan Kuman Isolat Urin Asal Rumah Sakit dan Non-Rumah Sakit Pada Triwulan I Tahun 1994. Jurnal PAMKI 1994; 7 (1): 7-13, Desember. 
11. Dzen SM. Multiresisten Acinetobacter anitratus yang di Isolasi dari Bahan Pemeriksaan Klinik. Jurnal PAMKI 1996; 7 : 2.

12. Noorhamdani. Pola Kuman Isolat Biakan Urin dan Pola Resistensinya Terhadap Antibiotika di RSUD dr Saiful Anwar Malang. Majalah Kedokteran Universitas Brawijaya 1995; 11: 43-52.

13. Noorhamdani. Isolat Acinetobacter baumannii dari Biakan Urin dan Tes Kepekaannya Terhadap beberapa Antibiotik. Majalah Kedokteran Universitas Brawijaya 2001; 17: 55-58

14. Kasminem. Pola Kuman Isolat Penyebab Infeksi Saluran Kemih dan Pola Resistensinya Terhadap Antibiotika di RSUD dr Saiful Anwar Malang. Karya Tulis Sebagai Tugas Akhir, Depkes RI, Politeknik Kesehatan Surabaya Jurusan Analis Kesehatan, 2002.

15. Noorhamdani. Aktivitas Hemaglutinasi Bakteri Acinetobacter baumannii yang Berasal dari Spesimen Klinik dan Lingkungan. Jurnal Kedokteran Brawijaya (JKB) 2004; 20: 2: 105-109.

16. Santoso S. Protein Adhesin Salmonella typhi Sebagai Faktor Virulensi Berpotensi Imunogenik Terhadap Produksi S-IgA Protektif. [Disertasi] Surabaya: Program Pasca Sarjana Universitas Airlangga, 2002.

17. Sumarno. Karakterisasi Molekuler Protein Adesi Vibrio cholerae 01 M094V dan Protein Reseptornya pada Sel Epitel Usus Halus Tikus Putih (Wistar). Studi Patogenesis Vibrio cholerae 01 M094V. [Disertasi]. Surabaya: Program Pasca Sarjana Universitas Airlangga, 2000.

18. Kimura A, Mountzouros KT, Relman DA, Falkow S, Cowell JL. Bordetella pertussis Filamentous Hemaglutinin: Evaluation as a Protective Antigen and Colonization Factor in a Mouse Respiratory Infection Model. Infect Immun 1990; 58:7-16.

19. Salyers AA and Whitt DD. Bacterial Pathogenesis A Molecular Approach. Washington DC: ASM Press; 1994.

20. Salyers AA and Whitt DD. Bacterial Pathogenesis A Molecular Approach. Washington DC: ASM Press; 2002.

21. Campos JM, McNamara AM and Howard BJ. Specimen collection and Processing. In: Clinical and Pathogenic Microbiology, $2^{\text {nd }}$ ed. Howard BJ et al (eds.), St Louis, Washington DC, Toronto: CV Mosby Co.; 1994; 213-242.

22. Arthur M, Johnson CE, Rubin RH, Rubin RH, Arbeit RD, Campanelli C, Kim C, Steinbach S, Agarwal M, Wilkinson R, and Goldstein R. Molecular Epidemiology of Adhesin and Hemolysin Virulence Factors among Uropathogenic Escherichia coli. Infect Immun 1989; 57: 303-313.

23. Microbact System 24E for the Identification of Miscellaneous Gram Negative Bacilli, (tanpa tahun). 3-rd ed. Adelaide, South Australia: Disposible Products Pty.Ltd.

24. McGarey DJ and Allred DR. Characterization of Hemaglutinating Components on the Anaplasma marginale. Initial Body Surface and Identification of Possible Adhesins. Infect Immun 1994; 62: 4587-4593.

25. Ehara M, Ishibashi M, Ichinose Y, Iwanaga M, Shimotori S, Naito T. Purification and Partial Characterization of Fimbriae of Vibrio cholerae 01. Vaccin 1987; 5: 283 - 286.

26. Laemmli UK. Cleavage of Structural Protein during the Assembly of the Head of Bacteriophage T4. Nature 1970; 227: 680-686.

27. Nagayama K, Oguchi T, Arita M, Honda T. Purification and Characterizations of a Cell-Associated Hemaglutinin of Vibrio parahaemolyticus. Infect Immun 1995; 63: 1987-1992.

28. Becker JM, Caldwell GA and Zachgo EA. Biotechnology a Laboratory Course. San Diego, New York: Academic Press Inc.; 1990; 193-194.

29. Martino PD, Bertin Y, Girardeau JP, Livrelli V, Joly B, Darfeuille-Michaud A. Molecular Characterization and Adhesive Properties of CF29K, an Adhesin of Klebsiella pneumoniae Strain Involved in Nosocomial Infection. Infect Immun 1995; 63: 4336-4344.

30. Winarsih S, Sumarno dan Roekistiningsih. Kajian Fungsi dan Sifat Immunogenitas Protein Hemaglutinin 32kD dan 20kD pada Helicobacter pylori. Majalah Kedokteran Universitas Brawijaya 1997; 13: 135-141.

31. Musa MS dan Nasution AH. Perancangan dan Analisa Percobaan IImiah. Depdikbud-Dirjen Dikbud, PAU-IPB; 1989.

32. Brooks GF, Butel JS, and Morse SA. Jawetz, Melnick and Adelberg's Medical Microbiology, 21th ed. Stamford, Connecticut: Appleton \& Lange; 1998.

33. Schreckenberger PC and von Graevenitz A. Acinetobacter, Achromobacter, Alcaligenes, Moraxella, Methylobacterium, and other Nonfermentative Gram-Negative Rods. In: Manual of Clinical Micrbiology, Murray PR, Baron EJ, Pfaller MA, Tenover FC, Yolken RH (eds.). Washington DC: ASM Press; 1999; 539-543.

34. Progulske-Fox A, Tumwasorn S and Holt S. The Expression and Function of a Bacteroides gingivalis Hemaglutinin gene in Escherichia coli. Oral Microbiol Immunol 1989; 4: 121-131.

35. Hechemy KE, Samsonoff WA, Harris HL and McKee M. Adherence and Entry of Borrelia burgdoferi in Vero cells. J Med Microbiol 1992; 36: 229-238. 
36. Chmiela M, Ringner M and Wadstrom T. Detection of Cell Surface Haemaglutinins of Helicobacter pylori. In: Helicobacter pylori: Techniques for Clinical Diagnosis and Basic Research. Lee A, and Megraud F, (eds.). London, Philadelphia, Toronto, Sidney, Tokyo: WB Saunders Co.; 1996; 213-223.

37. Alam M, Miyoshi S, Tomochika K, Shinoda S. Vibrio mimicus Attaches to The Intestinal Mucosa by Outer Membran Hemaglutinin Specific to Polypeptide Moities of Glycoprotein. Infect Immun 1997; 65: 3662-3665.

38. Evans DG, Evans DJ, Moulds JJ, Graham DY. N-Acetyl- neuraminyllactose-Binding Fibrillar Hemagglutinin of Campylobacter pylori: a Putative Colonization Factor Antigen. Infect Immun 1988; 56: 2896-2906.

39. O'Hanley P. Prospect for Urinary Tract Infection Vaccines. In: Urinary Tract Infections, Molecular Pathogenesis and Clinical Management. Mobley HLT and Warren JW (eds.), Washington DC: ASM Press; 1996; 417.

40. Nakazawa T, Ishibashi M, Konishi H, Takemoto T, Shigeeda M and Kochiyama T. Hemaglutination Activity of Campylobacter pylori. Infect Immun 1989; 57: 989-991.

41. Robertson MS, Cade JF, Savoia HF and Clancy RL. Helicobacter pylori Infection in the Australian Community: Current Prevalence and Lack of Association with ABO Nlood Group. Intern Med J. 2003; 33 (4): 163-167.

42. Shankar SG, Rajjith MS, Ranganathan S, Sivaramakhrisnana M, Natarajan V and Rasool SK. Role of Blood Groups in the Infection rate of Dandruff Caused by Pityrosporum ovale. Indian J Dermatol 2002; 47 (1): 21-23.

43. Hutson AM, Atmar RL, Graham DY and Estes MK. Norwalk Virus Infection and Disease is Associated with ABO HistoBlood Group Type. J Infect Dis 2002; 185 (9): 1335-1337.

44. Soto GE and Hultgren SJ. Bacterial Adhesins: Common Themes and Variations in Architecture and Assembly (Minireview). Infect Immun 1999; 181: 1059-1071.

45. Barza M. Urinary Tract. In: Mechanisms of Microbial Disease, $2^{\text {nd }}$ ed., Schaechter M, Medoff G and Eisenstein BI (eds.). Baltimore: William and Wilkins; 1993; $891-898$. 

Noorhamdani, Protein Fibria 16 kDa Bakterir ........ 59 